\title{
NEGARA HUKUM INDONESIA
}

\author{
Angga Saputra \\ Email: 2010003600207@unespadang.ac.id \\ No BP: 2010003600207 \\ Universitas Ekasakti Padang
}

\section{A. PENDAHULUAN}

Di jaman yang modern seperti saat ini, banyak negara-negara di dunia menggunakan konsep negara hukum sebagai suatu sistem dalam menjalankan negaranya atau dapat pula dikatakan bahwa hampir semua negara menyebut dirinya negara hukum, sehingga adalah tidak populer lagi mengaku negaranya sebagai negara kekuasaan. Sekalipun bentuk negara itu adalah monarki, negara itu adalah monarki konstitutional, misalnya Britania Raya, negara Belanda. Ternyata tidak semudah itu untuk mengaku sebagai negara hukum. Atau dengan mengatakan bahwa pemerintahnya selalu bertindak berdasar hukum yang berlaku, bukan berarti negara itu dapat disebut sebagai negara hukum.

Di dalam negara penganut negara hukum, maka hukum sebagai dasar diwujudkan dalam peraturan perundang-undangan yang berpuncak pada konstitusi, dimana dalam konstitusi berisi kesepakatan/konsensus bersama atau daat diartikan sebagai hukum dasar negara. Dengan demikian di dalam negara hukum, kekuasaan negara berdasar atas hukum dan konstitusi bukan berdasarkan kekuasaan belaka.

Konsep negara hukum di suatu negara tidak dapat dipaksakan ke negara lainnya. Tidak dapat dipungkiri bahwa perkembangan hukum di dunia telah melalui transformasi yang panjang. Tiap negara memiliki cara yang berbeda dalam mengembangkan hukum yang sesuai pandangan hidup (way of life) dan cara hidup. Sejarah hukum tiap negara tidak ada yang sama, masing-masing memiliki ciri tersendiri. Demikian pula Indonesia yang memiliki perjalanan sejarah sendiri. Indonesia memiliki ideologi Pancasila yang dengan menerapkannya secara konsisten, sekiranya dapat menjadi negara hukum yang membahagiakan rakyatnya.

Sistem hukum sangat berhubungan dengan ide, cita-cita dan tujuan dari masyarakatnya. Hukum mencerminkan kecerdasan, sosial, ekonomi, dan iklim politik pada waktunya. Maksud dari negara hukum ialah bahwa tidak ada satu pun yang berada di atas hukum dan hukumlah yang berkuasa. Penyeleggaraan kekuasaan pemerintahan harus didasarkan atas hukum, bukan titah kepala negara. Negara dan lembaga-lembaga lain dalam bertindak apapun harus dilandasi oleh hukum dan dapat dipertanggung jawabkan secara 
hukum. Kekuasaan menjalankan pemerintahan berdasarkan kedaulatan hukum (supremasi hukum) dan bertujuan untuk menyelenggarakan ketertiban hukum.

Pembahasan tentang negara hukum pada hakikatnya persoalan tentang kekuasaan. Indonesia sebagai Negara dua sentra kekuasaan, di satu pihak terdapat negara dengan kekuasaan yang menjadi syarat mutlak untuk dapat memerintah, dan di pihak lain, rakyat yang diperintah segan melepaskan segala kekuasaannya. Apabila penguasa di suatu negara hanya bertujuan untuk memperoleh kekuasaan sebesar-besarnya tanpa menghiraukan kebebasan rakyatnya, maka lenyaplah negara hukum.

\section{B. PEMBAHASAN}

Dalam rangka perubahan Undang-Undang Dasar Negara Republik Indonesia Tahun 1945, maka dalam Perubahan Keempat pada tahun 2002, konsepsi Negara Hukum atau "Rechtsstaat" yang sebelumnya hanya tercantum dalam Penjelasan UUD 1945, dirumuskan dengan tegas dalam Pasal 1 ayat (3) yang menyatakan, "Negara Indonesia adalah Negara Hukum.” Dalam konsep Negara Hukum itu, diidealkan bahwa yang harus dijadikan panglima dalam dinamika kehidupan kenegaraan adalah hukum, bukan politik ataupun ekonomi. Karena itu, jargon yang biasa digunakan dalam bahasa Inggeris untuk menyebut prinsip Negara Hukum adalah 'the rule of law, not of man'.

Maksud dari negara hukum ialah bahwa tidak ada satu pun yang berada di atas hukum dan hukumlah yang berkuasa. Penyeleggaraan kekuasaan pemerintahan harus didasarkan atas hukum, bukan titah kepala negara. Negara dan lembaga-lembaga lain dalam bertindak apapun harus dilandasi oleh hukum dan dapat dipertanggung jawabkan secara hukum. Kekuasaan menjalankan pemerintahan berdasarkan kedaulatan hukum (supremasi hukum) dan bertujuan untuk menyelenggarakan ketertiban hukum.

Menurut Julius Stahl, konsep Negara Hukum yang disebutnya dengan istilah 'rechtsstaat' itu mencakup empat elemen penting, yaitu:

1. Perlindungan hak asasi manusia.

2. Pembagian kekuasaan.

3. Pemerintahan berdasarkan undang-undang.

4. Peradilan tata usaha Negara.

Sedangkan A.V. Dicey menguraikan adanya tiga ciri penting dalam setiap Negara Hukum yang disebutnya dengan istilah "The Rule of Law", yaitu:

1. Supremacy of Law. 
2. Equality before the law.

3. Due Process of Law.

Keempat prinsip 'rechtsstaat' yang dikembangkan oleh Julius Stahl tersebut di atas pada pokoknya dapat digabungkan dengan ketiga prinsip 'Rule of Law' yang dikembangkan oleh A.V. Dicey untuk menandai ciri-ciri Negara Hukum modern di zaman sekarang. Bahkan, oleh "The International Commission of Jurist", prinsip-prinsip Negara Hukum itu ditambah lagi dengan prinsip peradilan bebas dan tidak memihak (independence and impartiality of judiciary) yang di zaman sekarang makin dirasakan mutlak diperlukan dalam setiap negara demokrasi. Prinsip-prinsip yang dianggap ciri penting Negara Hukum menurut "The International Commission of Jurists" itu adalah:

1. Negara harus tunduk pada hukum.

2. Pemerintah menghormati hak-hak individu.

3. Peradilan yang bebas dan tidak memihak.

Scheltema, merumuskan pandangannya tentang unsur unsur dan asas-asas Negara Hukum itu secara baru, yaitu meliputi 5 (lima) hal sebagai berikut:

1. Pengakuan, penghormatan, dan perlindungan Hak Asasi Manusia yang berakar dalam penghormatan atas martabat manusia (human dignity).

2. Berlakunya asas kepastian hukum. Negara Hukum untuk bertujuan menjamin bahwa kepastian hukum terwujud dalam masyarakat. Hukum bertujuan untuk mewujudkan kepastian hukum dan prediktabilitas yang tinggi, sehingga dinamika kehidupan bersama dalam masyarakat bersifat 'predictable'. Asas-asas yang terkandung dalam atau terkait dengan asas kepastian hukum itu adalah:

a. Asas legalitas, konstitusionalitas, dan supremasi hukum;

b. Asas undang-undang menetapkan berbagai perangkat peraturan tentang cara pemerintah dan para pejabatnya melakukan tindakan pemerintahan;

c. Asas non-retroaktif perundang-undangan, sebelum mengikat undang-undang harus lebih dulu diundangkan dan diumumkan secara layak;

d. Asas peradilan bebas, independent, imparial, dan objektif, rasional, adil dan manusiawi;

e. Asas non-liquet, hakim tidak boleh menolak perkara karena alasan undang-undangnya tidak ada atau tidak jelas;

f. Hak asasi manusia harus dirumuskan dan dijamin perlindungannya dalam undang-undang atau UUD. 
3. Berlakunya Persamaan (Similia Similius atau Equality before the Law) dalam Negara Hukum, Pemerintah tidak boleh mengistimewakan orang atau kelompok orang tertentu, atau memdiskriminasikan orang atau kelompok orang tertentu. Di dalam prinsip ini, terkandung:

(a) adanya jaminan persamaan bagi semua orang di hadapan hukum dan pemerintahan,

(b) tersedianya mekanisme untuk menuntut perlakuan yang sama bagi semua warga Negara.

4. Asas demokrasi dimana setiap orang mempunyai hak dan kesempatan yang sama untuk turut serta dalam pemerintahan atau untuk mempengaruhi tindakan-tindakan pemerintahan. Untuk itu asas demokrasi itu diwujudkan melalui beberapa prinsip, yaitu:

a. Adanya mekanisme pemilihan pejabat-pejabat publik tertentu yang bersifat langsung, umum, bebas, rahasia, jujur dan adil yang diselenggarakan secara berkala;

b. Pemerintah bertanggungjawab dan dapat dimintai pertanggungjawaban oleh badan perwakilan rakyat;

c. Semua warga Negara memiliki kemungkinan dan kesempatan yang sama untuk berpartisipasi dalam proses pengambilan keputusan politik dan mengontrol pemerintah;

d. Semua tindakan pemerintahan terbuka bagi kritik dan kajian rasional oleh semua pihak;

e. Kebebasan berpendapat/berkeyakinan dan menyatakan pendapat;

f. Kebebasan pers dan lalu lintas informasi;

g. Rancangan undang-undang harus dipublikasikan untuk memungkinkan partisipasi rakyat secara efektif.

5. Pemerintah dan Pejabat mengemban amanat sebagai pelayan masyarakat dalam rangka mewujudkan kesejahteraan masyarakat sesuai dengan tujuan bernegara yang bersangkutan. Dalam asas ini terkandung hal-hal sebagai berikut:

a. Asas-asas umum peerintahan yang layak;

b. Syarat-syarat fundamental bagi keberadaan manusia yang bermartabat manusiawi dijamin dan dirumuskan dalam aturan perundang-undangan, khususnya dalam konstitusi;

c. Pemerintah harus secara rasional menata tiap tindakannya, memiliki tujuan yang jelas dan berhasil guna (doelmatig). Artinya, pemerintahan itu harus diselenggarakan secara efektif dan efisien.

Pandangan tentang negara hukum yang patut diperhatikan adalah dari Jimly Asshiddiqie, dimana pandangannya terhadap negara hukum terdapat didalam sebuah artikel 
yang berjudul "Gagasan Negara Hukum Indonesia" dimana, ia merumuskan tiga belas prinsip pokok negara hukum modern. Ketiga-belas prinsip pokok tersebut merupakan pilar pilar utama yang menyangga berdiri tegaknya satu negara modern sehingga dapat disebut sebagai Negara Hukum (The Rule of Law, ataupun Rechtsstaat) dalam arti yang sebenarnya, yaitu:

\section{Supremasi Hukum (Supremacy of Law)}

Adanya pengakuan normatif dan empirik akan prinsip supremasi hukum, yaitu bahwa semua masalah diselesaikan dengan hukum sebagai pedoman tertinggi. Dalam perspektif supremasi hukum (supremacy of law), pada hakikatnya pemimpin tertinggi negara yang sesungguhnya, bukanlah manusia, tetapi konstitusi yang mencerminkan hukum yang tertinggi.

\section{Persamaan dalam Hukum (Equality before the Law)}

Adanya persamaan kedudukan setiap orang dalam hukum dan pemerintahan, yang diakui secara normative dan dilaksanakan secara empirik. Dalam rangka prinsip persamaan ini, segala sikap dan tindakan diskriminatif dalam segala bentuk dan manifestasinya diakui sebagai sikap dan tindakan yang terlarang, kecuali tindakantindakan yang bersifat khusus dan sementara yang dinamakan 'affirmative actions' guna mendorong dan mempercepat kelompok masyarakat tertentu atau kelompok warga masyarakat tertentu untuk mengejar kemajuan sehingga mencapai tingkat perkembangan yang sama dan setara dengan kelompok masyarakat kebanyakan yang sudah jauh lebih maju. Kelompok masyarakat tertentu yang dapat diberikan perlakuan khusus melalui 'affirmative actions' yang tidak termasuk pengertian diskriminasi itu misalnya adalah kelompok masyarakat suku terasing atau kelompok masyarakat hukum adaptasi tertentu yang kondisinya terbelakang. Sedangkan kelompok warga masyarakat tertentu yang dapat diberi perlakuan khusus yang bukan bersifat diskriminatif, misalnya, adalah kaum wanita ataupun anak-anak terlantar.

\section{Asas Legalitas (Due Process of Law)}

Dalam setiap Negara Hukum, dipersyaratkan berlakunya asas legalitas dalam segala bentuknya (due process of law), yaitu bahwa segala tindakan pemerintahan harus didasarkan atas peraturan perundang-undangan yang sah dan tertulis. Peraturan perundang-undangan tertulis tersebut harus ada dan berlaku lebih dulu atau mendahului tindakan atau perbuatan administrasi yang dilakukan. Dengan demikian, setiap perbuatan atau tindakan administrasi harus didasarkan atas aturan atau 'rules and procedures' (regels). 


\section{Pembatasan Kekuasaan}

Adanya pembatasan kekuasaan Negara dan organ-organ Negara dengan cara menerapkan prinsip pembagian kekuasaan secara vertikal atau pemisahan kekuasaan secara horizontal. Sesuai dengan hukum besi kekuasaan, setiap kekuasaan pasti memiliki kecenderungan untuk berkembang menjadi sewenangwenang, seperti dikemukakan oleh Lord Acton: "Power tends to corrupt, and absolute power corrupts absolutely". Karena itu, kekuasaan selalu harus dibatasi dengan cara memisah-misahkan kekuasaan ke dalam cabang-cabang yang bersifat 'checks and balances' dalam kedudukan yang sederajat dan saling mengimbangi dan mengendalikan satu sama lain. Pembatasan kekuasaan juga dilakukan dengan membagi-bagi kekuasaan ke dalam beberapa organ yang tersusun secara vertical. Dengan begitu, kekuasaan tidak tersentralisasi dan terkonsentrasi dalam satu organ atau satu tangan yang memungkinkan terjadinya kesewenang-wenangan.

\section{Organ-Organ Campuran Yang Bersifat Independen}

Dalam rangka membatasi kekuasaan itu, di zaman sekarang berkembang pula adanya pengaturann kelembagaan pemerintahan yang bersifat 'independent', seperti bank sentral, organisasi tentara, dan organisasi kepolisian. Selain itu, ada pula lembaga-lembaga baru seperti Komisi Hak Asasi Manusia, Komisi Pemilihan Umum (KPU), Komisi Ombudsman Nasional (KON), Komisi Penyiaran Indonesia (KPI), dan lain sebagainya. Lembaga, badan atau organisasi-organisasi ini sebelumnya dianggap sepenuhnya berada dalam kekuasaan eksekutif, tetapi sekarang berkembang menjadi independen sehingga tidak lagi sepenuhnya merupakan hak mutlak seorang kepala eksekutif untuk menentukan pengangkatan ataupun pemberhentian pimpinannya. Independensi lembaga atau organ-organ tersebut dianggap penting untuk menjamin demokrasi, karena fungsinya dapat disalahgunakan oleh pemerintah untuk melanggengkan kekuasaan. Misalnya, fungsi tentara yang memegang senjata dapat dipakai untuk menumpang aspirasi prodemokrasi, bank sentral dapat dimanfaatkan untuk mengontrol sumber-sumber kekuangan yang dapat dipakai untuk tujuan mempertahankan kekuasaan, dan begitu pula lembaga atau organisasi lainnya dapat digunakan untuk kepentingan kekuasaan. Karena itu, independensi lembaga-lembaga tersebut dianggap sangat penting untuk menjamin prinsip negara hukum dan demokrasi. 


\section{Peradilan Bebas dan Tidak Memihak}

Adanya peradilan yang bebas dan tidak memihak (independent and impartial judiciary). Peradilan bebas dan tidak memihak ini mutlak harus ada dalam setiap Negara Hukum. Dalam menjalankan tugas judisialnya, hakim tidak boleh dipengaruhi oleh siapapun juga, baik karena kepentingan jabatan (politik) maupun kepentingan uang (ekonomi). Untuk menjamin keadilan dan kebenaran, tidak diperkenankan adanya intervensi ke dalam proses pengambilan putusan keadilan oleh hakim, baik intervensi dari lingkungan kekuasaan eksekutif maupun legislative ataupun dari kalangan masyarakat dan media massa. Dalam menjalankan tugasnya, hakim tidak boleh memihak kepada siapapun juga kecuali hanya kepada kebenaran dan keadilan. Namun demikian, dalam menjalankan tugasnya, proses pemeriksaan perkara oleh hakim juga harus bersifat terbuka, dan dalam menentukan penilaian dan menjatuhkan putusan, hakim harus menghayati nilai-nilai keadilan yang hidup di tengah-tengah masyarakat. Hakim tidak hanya bertindak sebagai 'mulut' undangundang atau peraturan perundang-undangan, melainkan juga 'mulut' keadilan yang menyuarakan perasaan keadilan yang hidup di tengah-tengah masyarakat.

\section{Peradilan Tata Usaha Negara}

Meskipun peradilan tata usaha negara juga menyangkut prinsip peradilan bebas dan tidak memihak, tetapi penyebutannya secara khusus sebagai pilar utama Negara Hukum tetap perlu ditegaskan tersendiri. Dalam setiap Negara Hukum, harus terbuka kesempatan bagi tiap-tiap warga negara untuk menggugat keputusan pejabat administrasi Negara dan dijalankannya putusan hakim tata usaha negara (administrative court) oleh pejabat administrasi negara. Pengadilan Tata Usaha Negara ini penting disebut tersendiri, karena dialah yang menjamin agar warga negara tidak didzalimi oleh keputusan-keputusan para pejabat administrasi negara sebagai pihak yang berkuasa. Jika hal itu terjadi, maka harus ada pengadilan yang menyelesaikan tuntutan keadilan itu bagi warga Negara, dan harus ada jaminan bahwa putusan hakim tata usaha Negara itu benar-benar djalankan oleh para pejabat tata usaha Negara yang bersangkutan. Sudah tentu, keberadaan hakim peradilan tata usaha negara itu sendiri harus pula dijamin bebas dan tidak memihak sesuai prinsip 'independent and impartial judiciary' tersebut di atas.

\section{Peradilan Tata Negara (Constitutional Court)}

Di samping adanya pengadilan tata usaha negara yang diharapkan memberikan jaminan tegaknya keadilan bagi tiap-tiap warga negara, Negara Hukum modern juga lazim 
mengadopsikan gagasan mahkamah konstitusi dalam sistem ketatanegaraannya, baik dengan pelembagaannya yang berdiri sendiri di luar dan sederajat dengan Mahkamah Agung ataupun dengan mengintegrasikannya ke dalam kewenangan Mahkamah Agung yang sudah ada sebelumnya. Pentingnya peradilan ataupun mahkamah konstitusi (constitutional court) ini adalah dalam upaya memperkuat sistem 'checks and balances' antara cabang-cabang kekuasaan yang sengaja dipisah-pisahkan untuk menjamin demokrasi. Misalnya, mahkamah ini diberi fungsi pengujian konstitusionalitas undang-undang yang merupakan produk lembaga legislatif, dan memutus berkenaan dengan berbagai bentuk sengketa antar lembaga negara yang mencerminkan cabang-cabang kekuasaan negara yang dipisah-pisahkan. Keberadaan mahkamah konstitusi ini di berbagai negara demokrasi dewasa ini makin dianggap penting dan karena itu dapat ditambahkan menjadi satu pilar baru bagi tegaknya Negara Hukum modern.

\section{Perlindungan Hak Asasi Manusia:}

Adanya perlindungan konstitusional terhadap hak asasi manusia dengan jaminan hukum bagi tuntutan penegakannya melalui proses yang adil. Perlindungan terhadap hak asasi manusia tersebut dimasyarakatkan secara luas dalam rangka mempromosikan penghormatan dan perlindungan terhadap hak-hak asasi manusia sebagai ciri yang penting suatu Negara Hukum yang demokratis. Setiap manusia sejak kelahirannya menyandang hak-hak dan kewajiban-kewajiban yang bersifat bebas dan asasi. Terbentuknya Negara dan demikian pula penyelenggaraan kekuasaan suatu Negara tidak boleh mengurangi arti atau makna kebebasan dan hak-hak asasi kemanusiaan itu. Karena itu, adanya perlindungan dan penghormatan terhadap hak-hak asasi manusia itu merupakan pilar yang sangat penting dalam setiap Negara yang disebut sebagai Negara Hukum. Jika dalam suatu Negara, hak asasi manusia terabaikan atau dilanggar dengan sengaja dan penderitaan yang ditimbulkannya tidak dapat diatasi secara adil, maka Negara yang bersangkutan tidak dapat disebut sebagai Negara Hukum dalam arti yang sesungguhnya.

\section{Bersifat Demokratis (Democratische Rechtsstaat)}

Dianut dan dipraktekkannya prinsip demokrasi atau kedaulatan rakyat yang menjamin peranserta masyarakat dalam proses pengambilan keputusan kenegaraan, sehingga setiap peraturan perundang-undangan yang ditetapkan dan ditegakkan mencerminkan nilai-nilai keadilan yang hidup di tengah masyarakat. Hukum dan peraturan perundang-undangan yang berlaku, tidak boleh ditetapkan dan diterapkan secara sepihak oleh dan/atau hanya untuk kepentingan penguasa secara bertentangan dengan prinsip-prinsip demokrasi. Karena hukum 
tidak dimaksudkan hanya menjamin kepentingan segelintir orang yang berkuasa, melainkan menjamin kepentingan akan rasa adil bagi semua orang tanpa kecuali. Dengan demikian, cita negara hukum (rechtsstaat) yang dikembangkan bukanlah 'absolute rechtsstaat', melainkan 'democratische rechtsstaat' atau negara hukum yang demokratis. Dalam setiap Negara Hukum yang bersifat nomokratis harus dijamin adanya demokrasi, sebagaimana di dalam setiap Negara Demokrasi harus dijamin penyelenggaraannya berdasar atas hukum.

\section{Berfungsi sebagai Sarana Mewujudkan Tujuan Bernegara (Welfare Rechtsstaat)}

Hukum adalah sarana untuk mencapai tujuan yang diidealkan bersama. Cita-cita hukum itu sendiri, baik yang dilembagakan melalui gagasan negara demokrasi (democracy) maupun yang diwujudkan melalaui gagasan negara hukum (nomocrasy) dimaksudkan untuk meningkatkan kesejahteraan umum. Bahkan sebagaimana cita-cita nasional Indonesia yang dirumuskan dalam Pembukaan UUD 1945, tujuan bangsa Indonesia bernegara adalah dalam rangka melindungi segenap bangsa Indonesia dan seluruh tumpah darah Indonesia, memajukan kesejahteraan umum, mencerdaskan kehidupan bangsa, dan ikut melaksanakan ketertiban dunia berdasarkan kemerdekaan, perdamaian abadi dan keadilan sosial. Negara Hukum berfungsi sebagai sarana untuk mewujudkan dan mencapai keempat tujuan bernegara Indonesia itu. Dengan demikian, pembangunan negara Indonesia tidak terjebak menjadi sekedar 'rule-driven', melainkan 'mission driven', yang didasarkan atas aturan hukum.

\section{Transparansi dan Kontrol Sosial}

Adanya transparansi dan kontrol sosial yang terbuka terhadap setiap proses pembuatan dan penegakan hukum, sehingga kelemahan dan kekurangan yang terdapat dalam mekanisme kelembagaan resmi dapat dilengkapi secara komplementer oleh peranserta masyarakat secara langsung (partisipasi langsung) dalam rangka menjamin keadilan dan kebenaran. Adanya partisipasi langsung ini penting karena sistem perwakilan rakyat melalui parlemen tidak pernah dapat diandalkan sebagai satu-satunya saluran aspirasi rakyat. Karena itulah, prinsip 'representation in ideas' dibedakan dari 'representation in presence', karena perwakilan fisik saja belum tentu mencerminkan keterwakilan gagasan atau aspirasi. Demikian pula dalam penegakan hukum yang dijalankan oleh aparatur kepolisian, kejaksaan, pengacara, hakim, dan pejabat lembaga pemasyarakatan, semuanya memerlukan kontrol sosial agar dapat bekerja dengan efektif, efisien serta menjamin keadilan dan kebenaran. 


\section{BerKetuhanan Yang Maha Esa}

Khusus mengenai cita Negara Hukum Indonesia yang berdasarkan Pancasila, ide kenegaraan kita tidak dapat dilepaskan pula dari nilai Ketuhanan Yang Maha Esa yang merupakan sila pertama dan utama Pancasila. Karena itu, di samping ke-12 ciri atau unsur yang terkandung dalam gagasan Negara Hukum Modern seperti tersebut di atas, unsur ciri yang ketigabelas adalah bahwa Negara Hukum Indonesia itu menjunjung tinggi nilai-nilai ke-Maha Esaan dan ke-Maha Kuasa-an Tuhan. Artinya, diakuinya prinsip supremasi hukum tidak mengabaikan keyakinan mengenai ke-Maha Kuasa-an Tuhan Yang Maha Esa yang diyakini sebagai sila pertama dan utama dalam Pancasila. Karena itu, pengakuan segenap bangsa Indonesia mengenai kekuasaan tertinggi yang terdapat dalam hukum konstitusi di satu segi tidak boleh bertentangan dengan keyakinan segenap warga bangsa mengenai prinsip dan nilai-nilai Tuhan Yang Maha Esa itu, dan di pihak lain pengakuan akan prinsip supremasi hukum itu juga merupakan pengejawantahan atau ekspresi kesadaranrasional kenegaraan atas keyakinan pada Tuhan Yang Maha Esa yang menyebabkan setiap manusia Indonesia hanya memutlakkan Yang Esa dan menisbikan kehidupan antar sesama warga yang bersifat egaliter dan menjamin persamaan dan penghormatan atas kemajemukan dalam kehidupan bersama dalam wadah Negara Pancasila. Pancasila membuat Indonesia dapat menseleksi konsep negara hukum mana yang cocok diterapkan di Indonesia. Sebagai contoh, Indonesia bukanlah negara agama, tapi pengakuan agama sangat kuat di Indonesia, terbukti pada Pasal 29 ayat 2 UUD NRI 1945 bahwa Negara menjamin kemerdekaan tiap-tiap penduduk untuk memeluk agamanya masing- masing dan untuk beribadat menurut agamanya dan kepercayaannya itu.

Dalam sistem konstitusi Negara kita, Negara Hukum itu menjadi bagian yang tak terpisahkan dari perkembangan gagasan kenegaraan Indonesia sejak kemerdekaan. Meskipun dalam pasal-pasal UUD 1945 sebelum perubahan, ide Negara hukum itu tidak dirumuskan secara eksplisit, tetapi dalam Penjelasan ditegaskan bahwa Indonesia menganut ide 'rechtsstaat', bukan 'machtsstaat'. Dalam Konstitusi RIS Tahun 1949, ide negara hukum itu bahkan tegas dicantumkan. Demikian pula dalam UUDS Tahun 1950, kembali rumusan bahwa Indonesia adalah negara hukum dicantumkan dengan tegas. Oleh karena itu, dalam Perubahan Ketiga tahun 2001 terhadap UUD Negara Republik Indonesia Tahun 1945, ketentuan mengenai ini kembali dicantumkan tegas dalam Pasal 1 ayat (3) yang berbunyi: "Negara Indonesia adalah Negara Hukum”. Kiranya, cita negara hukum yang mengandung 13 ciri seperti uraian di atas 
itulah ketentuan Pasal 1 ayat (3) UUD Negara Republik Indonesia Tahun 1945 itu sebaiknya kita pahami.

\section{Unsur-unsur Negara Hukum dalam UUD 1945}

\section{a. Bersumber pada Pancasila}

Penjelasan Umum Bagian III UUD 1945 mengatakan bahwa Undang-Undang Dasar menciptakan pokok pikiran yang terkandung dalam pembukaan dan pasal-pasalnya. Pokok-pokok pikiran tersebut meliputi suasana kebatinan dari Undang-Undang Dasar Negara Indonesia. Pokok-pokok pikiran ini mewujudkan cita-cita hukum (rechtsidee) yang menguasai hukum dasar negara, baik hukum yang tertulis (Undang-Undang Dasar) maupun hukum yang tidak tertulis.

Oleh karena itu UUD 1945 sebagai hukum dasar tertinggi negara Indonesia tidak boleh bertentangan dengan Pancasila, akan tetapi harus bersumber dari Pancasila. Artinya Pancasila merupakan sumber hukum yang paling tinggi dari segala sumber hukum dalam negara hukum Indonesia, dan ketentuan tersebut dijadikan unsur pertama.

Pancasila sebagai dasar ideologi negara, sekiranya tepat untuk negara hukum Indonesia yang multi ras, multi kultur, multi etnis, multi agama, dan daerahnya sangat luas. Untuk meraih cita dan mencapai tujuan dengan landasan dan panduan tersebut maka sistem hukum nasional yang harus dibangun adalah sistem hukum Pancasila. Sistem hukum Pancasila merupakan sistem hukum yang tumbuh dengan kepentingan, nilai sosial, dan konsep keadilan ke dalam satu ikatan hukum prismatik dengan mengambil unsur- unsur baiknya.

Sebagai konsepsi prismatik, Pancasila mengandung unsur-unsur yang baik dan cocok dengan nilai khas budaya Indonesia yang sudah hidup di kalangan masyarakat selama berabadabad. Konsepsi prismatik ini minimal dapat dilihat dari empat hal;

1. Pertama, Pancasila memuat unsur yang baik dari pandangan individualisme dan kolektivisme. Diakui bahwa manusia sebagai pribadi mempunyai hak dan kebebasan asasi namun sekaligus melekat padanya kewajiban asasi sebagai makhluk Tuhan dan sebagai makhluk sosial.

2. Kedua, Pancasila mengintegrasikan konsep negara hukum "Rechtstaats" yang menekankan pada civil law dan kepastian hukum dan konsepsi negara hukum "the Rule of Law" yang menekankan pada common law dan rasa keadilan. 
3. Ketiga, Pancasila menerima hukum sebagai alat pembaruan masyarakat (law as tool of social engineering) sekaligus sebagai cermin rasa keadilan yang hidup di masyarakat (living law).

4. Keempat, Pancasila menganut paham religious nation state, bukan negara agama, tetapi juga tidak hampa agama (negara sekuler). Negara harus melindungi dan membina semua pemeluk agama

\section{b. Sistem Konstitusi}

Sistem konstitusi atau sistem hukum dasar merupakan dasar penyelenggaraan pemerintahan negara Indonesia, yang secara formalnya diatur dalam UUD 1945. Apabila negara berdasarkan hukum maka pemerintahan negara itu harus berdasar atas suatu konstitusi atau undang-undang dasar sebagai landasan penyelenggaraan pemerintahan. Konstitusi negara sebagai sarana pemersatu bangsa. Hubungan antar warga negara dengan negara, hubungan antar lembaga negar dan kinerja masing-masing elemen kekuasaan berada pada satu sistem aturan yang disepakati dan dijunjung tinggi

\section{c. Kedaulatan Rakyat}

Unsur ketiga dari negara hukum menurut UUD 1945 adalah ditetap kannya azas kedaulatan rakyat (volkssouvereiniteit) dalam penyeleggaraan ke-kuasaan negara. Rumusan mengenai kedaulatan rakyat ini dapat ditemu kan dalam Pembukaan UUD 1945 Alinea IV, yakni sebagai kedaulatan rakyat yang berdasarkan Pancasila. Kemudian lebih jelaskan dinyatakan dalam Pasal 1 ayat (2) UUD 1945, yang berbunyi: "Kedaulatan adalah di tangan rakyat dan dilaksanakan menurut Undang-Undang Dasar". Penjelasan Pasal 1 ayat (2) tersebut menyatakan bahwa sebenarnya rakyatlah sebagai pemegang kedaulatan negara tertinggi.

\section{d. Persamaan dalam Hukum}

Unsur keempat negara hukum yang dimuat dalam UUD 1945 adalah unsur persamaan dalam hukum (equality before the law). Unsur ini secara jelas dimuat dalam Pasal 27 ayat (1), yaitu: "Segala warga negara bersamaan kedudukannya di dalam hukum dan pemerintahan dan wajib menjunjung hukum dan pemerintahan itu dengan tidak ada kecualinya".

\section{e. Kekuasaan Kehakiman yang Bebas}

Terdapat beberapa pasal dalam UUD 1945 yang berkenaan dengan kekuasaan kehakiman, di antaranya Pasal 24 menyatakan bahwa:

1) Kekuasaan kehakiman merupakan kekuasaan yang merdeka untuk menyelenggarakan peradilan guna menegakkan hokum dan keadilan. 
2) Kekuasaan kehakiman dilakukan oleh sebuah Mahkamah Agung dan badan peradilan yang berada di bawahnya dalam lingkungan peradilan umum, lingkungan peradilan agama, lingkungan peradilan militer, lingkungan peradilan tata usaha Negara, dan oleh sebuah Mahkamah Konstitusi.

\section{f. Pembentukan Undang-undang}

Pembentukan undang-undang dalam UUD 1945 dilakukan oleh DPR bersama-sama dengan Presiden. DPR memberi persetujuan kepada setiap rancangan undang-undang dari pemerintah, begitu pula sebaliknya. Selain itu juga, DPR mempunyai hak inisiatif untuk mengajukan rancangan undang-undang. Ketentuan tersebut memberikan pemahaman bahwa dalam hal pembentukan undang-undang, maka pihak eksekutif mempunyai hubungan kerjasama yang erat dengan pihak legislatif. Unsur tersebut menurut Azhari merupakan perwujudan dari cita negara Pancasila, di mana pembentukan undang-undang dilakukan oleh mereka yang merumuskan bersama-sama dengan mereka yang akan melaksanakan undang-undang. Sedangkan kerja sama dilakukan karena untuk mengatasi kelambatan dan kekakuan dalam proses pembentukan undang-undang, terutama menyangkut pengetahuan dan tingkat kemampuan DPR dalam pembentukan undang - undang.

\section{PENUTUP}

Negara hukum Indonesia dapat diibaratkan sebagai sebuah proyek rumah, di mana dia harus dibangun, kemudian dirawat, lalu diwariskan pada penerusnya. Diperlukan penemuan jati diri atau identitas dalam pembentukannya. Dilihat dari sisi sejarah Indonesia mengikuti langkah Rechtsstaat atau civil law, karena Indonesia cukup lama dijajah oleh Belanda. Namun, jika konsep civil law ini diterapkan secara murni, kemungkinan besar tidak mendatangkan kebahagiaan bagi bangsa Indonesia. Hukum akan bergerak jauh lebih lambat daripada dinamika masyarakat Indonesia. Bahkan yang lebih buruk lagi, pelaksanaan pemerintahan akan bergerak kaku dan cenderung represif. Demikian juga dengan penerapan konsep Rule of Law secara murni, pengendalian negara pada masyarakat akan sangat lemah, sebab masyarakat Indonesia yang sangat plural dan tersebar.

Dapat ditegaskan bahwa Indonesia dengan Ideologi Pancasila yang dicantumkan dalam sebuah konstitusi, yaitu UUD NRI 1945, Indonesia dapat menjadi negara hukum yang membahagiakan rakyatnya, karena kemampuannya untuk memilih yang terbaik bagirakyatnya jika diterapkan secara konsisten. Apabila negara Indonesia benar-benar ingin membahagiakan 
rakyatnya, maka Indonesia harus mendapatkan kesetiaan rakyatnya. Harapan ideal ngeara

hukum Indonesia yang membahagiakan akan terus muncul, karena Indonesia bukanlah negara

yang statis, melainkan negara yang bergerak bersama dengan perubahan zaman.

\section{DAFTAR PUSTAKA}

Darmini Roza dan Laurensius Arliman S, Peran Pemerintah Daerah Di Dalam Melindungi Hak Anak Di Indonesia, Masalah-Masalah Hukum, Volume 47, Nomor 1, 2018. https://doi.org/10.14710/mmh.47.1.2018.10-21

Laurensius Arliman S, Peranan Metodologi Penelitian Hukum di Dalam Perkembangan Ilmu Hukum di Indonesia, Soumatera Law Review, Volume 1, Nomor 1, 201. http://doi.org/10.22216/soumlaw.v1i1.3346.

Laurensius Arliman S, Peran Badan Permusyawaratan Desa di Dalam Pembangunan Desa dan Pengawasan Keuangan Desa, Padjadjaran Journal of Law, Volume 4, Nomor 3, 2017. https://doi.org/10.15408/jch.v4i2.3433.

Laurensius Arliman S, Penanaman Modal Asing Di Sumatera Barat Berdasarkan UndangUndang Nomor 25 Tahun 2007 Tentang Penanaman Modal, Supremasi Hukum, Volume 1, Nomor 1, 2018. http://dx.doi.org/10.36441/hukum.v1i01.102 .

Laurensius Arliman S, Memperkuat Kearifan Lokal Untuk Menangkal Intoleransi Umat Beragama Di Indonesia, Ensiklopedia of Journal, Volume 1, Nomor 1, 2018, https://doi.org/10.33559/eoj.v1i1.18.

Laurensius Arliman S, Perkawinan Antar Negara Di Indonesia Berdasarkan Hukum Perdata Internasional, Kertha Patrika, Volume 39, Nomor 3, 2017, https://doi.org/10.24843/KP.2017.v39.i03.p03.

Laurensius Arliman S, Partisipasi Masyarakat Di Dalam Pengelolaan Uang Desa Pasca Undang-Undang Nomor 6 Tahun 2014 Tentang Desa, Jurnal Arena Hukum, Volume 12, Nomor 2, 2019, https://doi.org/10.21776/ub.arenahukum.2019.01202.5.

Laurensius Arliman S, Mewujudkan Penegakan Hukum Yang Baik Di Negara Hukum Indonesia, Dialogica Jurnalica, Volume 11, Nomor 1, 2019, https://doi.org/10.28932/di.v11i1.1831.

Laurensius Arliman S, Mediasi Melalui Pendekatan Mufakat Sebagai Lembaga Alternatif Penyelesaian Sengketa Untuk Mendukung Pembangunan Ekonomi Nasional, UIR Law Review, Volume 2, Nomor 2, 2018, https://doi.org/10.25299/uirlrev.2018.vol2(02).1587

Laurensius Arliman S, Peranan Filsafat Hukum Dalam Perlindungan Hak Anak Yang Berkelanjutan Sebagai Bagian Dari Hak Asasi Manusia, Doctrinal, Volume 1, Nomor 2, 2016.

Laurensius Arliman S, Ni Putu Eka Dewi, Protection of Children and Women's Rights in Indonesia through International Regulation Ratification, Journal of Innovation, Creativity and Change Volume 15, Nomor 6, 2021.

Laurensius Arliman S, Gagalnya Perlindungan Anak Sebagai Salah Satu Bagian Dari Hak Asasi Manusia Oleh Orang Tua Ditinjau Dari Mazhab Utilitarianisme, Jurnal Yuridis, Volume 3, Nomor 2, 2016, http://dx.doi.org/10.35586/.v3i2.180.

Laurensius Arliman S, Tantangan Pendidikan Kewarganegaraan Pada Revolusi 4.0, Jurnal Ensiklopedia Sosial Review, Volume 2, Nomor 3, 2020. 
